\title{
Comparison of Rainfall Excess Computation Techniques by Hydrological Model
}

Talat Farid Ahmed ${ }^{1 *}$, Ashfaq Ahmed Sheikh², Hashim Nisar Hashmi ${ }^{3}$ and Muhammad Azeem Afzal ${ }^{4}$

${ }^{1}$ Farm Operation and Services, National Agricultural Research Centre, Islamabad, Pakistan

${ }^{2}$ Pakistan Council of Research in Water Resources, Islamabad, Pakistan

${ }^{3}$ Civil Engineering Department, University of Engineering and Technology, Taxila, Pakistan

${ }^{4}$ Farm Operation and Services, National Agricultural Research Centre, Islamabad, Pakistan

\begin{abstract}
The hydrological investigations are fundamental to infrastructure development including roads, bridges and other social facilities. The rainfall-runoff analysis is central to all such hydrological analysis. Rainfall excess values are often used as input to various hydrological models for the designing of various hydraulic structures such as bridges, culverts, spillways and flood control works of all sort. This part has more uncertainties due to a complex nature of the watersheds and normally requires calibration of parameters involved in such relationships generally imperial in nature. Under the current study, an attempt has been made to evaluate an appropriate excess rainfall method by carrying out a comparative study on local catchments in Mangla watershed of Pakistan. Four methods namely 1) Initial and uniform loss rate 2) Exponential loss rate 3) SCS curve number, and 4) Holtan loss rate have been evaluated in the study, using HEC-1 computer package. A comparison has been made to see which method is the most effective method, applicable to the catchments for which parameters were optimized and also for other similar catchments. The study has been carried out on four different locations located in the same hydrological region. It has been concluded that Exponential method of rainfall excess is suitable for local conditions for catchments ranging up to 100 square miles. For larger areas, a catchment should be divided into sub-catchments for effective results. For a different catchment whether physically similar and located in a same hydrological region, a different set of optimized parameters is required.
\end{abstract}

Keywords: Rainfall excess methods; Flood hydrograph package; Hydraulic engineering crop; Semi-arid region

Abbreviations: STRKR: Initial value of loss coefficient; DLTKR: Initial loss; RTIOL: Loss-co-efficient recession constant; ERAIN: Exponent of precipitation; FC: Deep percolation rate; GIA: Co-efficient of SA; SA: Depth of available storage BEXP: Exponent of SA; STRTL: Initial loss; CNSTL: Uniform loss rate; CRVNBR: Curve Number; STRTL: Initial Abstraction.

\section{Introduction}

The infrastructure development including roads, bridges and other social facilities, has central role in the socio-economic uplift of the countries. All such developments require fundamental design considerations with the main objective to safeguard huge investments against natural disaster especially floods to avoid or at least reduce the severity of any such episode. Thus, attracts hydrological investigation using either stochastic approaches based on historical observations and/ or some rainfall-runoff relationships. Nevertheless, all such approaches and methods have inherent problems of suitable method or parameters selection.

The rainfall-runoff methods mainly have two components viz., i) excess rainfall component to estimate effective portion of rainfall to generate runoff, and then ii) to convert the excess rainfall into runoff hydrograph. Rainfall excess also named as direct runoff is defined as the difference between total rainfall and that lost due to abstractions such as depression storage, interception, evaporation, and infiltration [1]. This part has more uncertainties due to a complex nature of the watersheds and normally requires calibration of parameters involved in such relationships generally imperial in nature. Each method thus has its own limitations based upon the assumptions applied to make the problem simple.

The hydrological process of excess rainfall involves the horizontal movement of water over the surface of the land. Surface runoff, also called overland flow, is generated by either excess rainfall or snowmelt. When surface runoff records are unavailable, as in the case of ungauged catchments, or if records are missing for various reasons from gauged catchments, surface runoff can be estimated by derived relationships. The most common techniques are correlation of runoff record with various catchment characteristics known as rainfall-runoff models [2].

In the case of ungauged catchments which are hydrologically similar in characteristics and preferably in close proximity to one or more gauged catchments, surface runoff can be derived by correlation. Standard regression analysis can be used to estimate flows for the ungauged catchments from gauged catchment(s). This method is relatively simple but care is required in selection of hydrologically similar catchments. Critical review of different methods indicates that the correlation method is not suitable for small time interval. Other methods are based on empirical relationships such as rational method. This method is mostly used for peak flow determination for smaller catchments. The Cook's and Cypress Greek model are also used for rainfall runoff computation [3].

*Corresponding author: Talat Farid Ahmed, Principal Scientific Officer, Farm Operation and Services, National Agricultural Research Centre, Islamabad Pakistan, Tel: +925190762404; E-mail: tafa367@gmail.com

Received August 21, 2017; Accepted August 28, 2017; Published September 04 2017

Citation: Ahmed TF, Sheikh AA, Hashmi HN, Afzal MA (2017) Comparison of Rainfall Excess Computation Techniques by Hydrological Model. Hydrol Current Res 8: 281. doi: 10.4172/2157-7587.1000281

Copyright: ( 2017 Ahmed TF, et al. This is an open-access article distributed under the terms of the Creative Commons Attribution License, which permits unrestricted use, distribution, and reproduction in any medium, provided the original author and source are credited. 
The Cook method cannot be expected to provide exact answers, since some factors that affect runoff are not considered. Such a method is useful in making quick estimation for projects where detailed hydrological studies are not justified [4].

The term "infiltration" has been used with diverse meanings, sometimes as a synonym of wetting, imbibition, percolation, or basin abstraction (loss). Usage, however, seems to have attached to the word infiltration a more restricted meaning. Infiltration is the phenomenon of water penetration from the surface of the ground into the adjacent soil [5]. The infiltration approach assumes that the surface runoff from a given storm is equal to the portion of the rainfall which is not disposed off [6].

Two methods of computing rainfall excess were compared in the U.S. Army Corps of Engineers flood hydrograph package (HEC-1) viz i) the initial and uniform method, and ii) exponential method. Rainfall and runoff data from 209 storms in 32-gauge basins in Illinois were used to calibrate the HEC-1 model. An evaluation of the mean errors indicated that although some bias in modeled hydrograph accuracy was evident, rainfall excess computed using either method resulted in a computed hydrograph accuracy that was within generally accepted limits [7].

Generally, the methods developed to compute excess rainfall up till now involve various parameters and co-efficient. The relationships between catchment characteristics and rainfall excess vary from region to region because they show the combined effect of all other characteristics which are not considered in the relationships. These coefficients and parameters may effect further applications. It follows that excess rainfall computation methods developed from one climatological region may not be applicable to the catchments from a different climatological region. For this reason, there is a need to carry out a comparative study to evaluate the best rainfall excess computation method for local conditions with the prime objectives of calibration of the excess rainfall methods for selected catchments, their comparison, and evaluate the best fit model(s) to recommend for future applications.

\section{Materials and Methods}

\section{Site description}

Study area is located in one hydrological region. Four catchments selected under this study are located in the sub-humid to humid region of Murree Hills, hilly part of Hazara and Pothohar (Awan). The study area is situated between latitude 363 to $35^{\circ}$ and longitude $72^{\circ}$ to $74^{\circ} \mathrm{E}$ in the North-Eastern part of Pakistan covering the basins ranging in area from 56 to 1080 square miles (Table 1). The average annual rainfall varies from 20 to 80 inches. Maximum rain occurs in the months of July to September. Maximum summer precipitation occurs as a result of seasonal low encountered by south eastern and western disturbances along with the effect of south eastern monsoons. Severe winter and mild summer temperature with summer dust storms takes place over low lands [8].

\section{Methodology}

There are many methods developed for estimating the volume and its distribution in time of rainfall excess from rainfall data and hydrological and physical characteristics of catchments.

The current study presents a comparison of four excess rainfall methods namely; 1) Initial and uniform loss rate, 2) Exponential loss rate, 3) Holtan loss rate, and 4) SCS curve number, using HEC1 model. The study has been carried out on four catchments ranging in size from 56 to 1080 square miles located in the vicinity of Tarbela
Dam in Pakistan. The comparative study of rainfall excess methods has been carried out in such a way that the suitable method could be recommended or local conditions. For this purpose, parameters involved in the methods were optimized using default values as given in the HEC-1. Individual parameters for four different catchments were optimized using several rainfall-runoff events. The major aim of the study was to evaluate a rainfall excess method appropriate for local conditions.

In order to compare excess rainfall computation techniques, the study was divided into two stages i.e., optimization of parameters, which involves the calibration and optimization of parameters present in the methods. The second stage is application, which involves the computation of excess rainfall for storms other than calibrated. For this purpose, four smaller catchments of same hydrological region with different physical features were used for rainfall excess computation. All these catchments have varying physical features (Table 1). These parameters were calibrated by "Hit and Trial" approach.

Optimization of parameters: Each of these methods had some parameters, which are required to be calibrated for different set of conditions. For calibration, a number of rainfall-runoff events for these basins were selected and used. Total averaged rainfall and rainfall excess were obtained by using suitable average rainfall and base flow separation methods.

In the HEC-1, to perform calibration, initial default values of parameters are available as given in Table 2. These default values were used as starting values for calibration with HEC-1 model. Excess rainfall derived from observed rainfall for respective storm was used to compare with the calibrated values. Calibrated values are accepted keeping in view the error as minimum as possible. This procedure was repeated for each method, for different number of storms and final optimized values of parameter were obtained for four basins. These parameters are given in Table 3 and also in Figure 1.

Application of optimized parameters: In order to see the effectiveness of the calibrated models, such optimized values of parameters were used to compute excess rainfall for storms other than calibrated for each of four methods. The results are presented in coming section.

\section{Results}

The optimized values of parameters were then applied for respective four catchments on storm events other than calibrated so that a comparison could be made.

\section{Results for Ling River near Kahota}

This study basin is 56 square miles in size and located at $33^{\circ} 34^{\circ}$ latitudes and $73^{\circ} 22^{\prime}$ longitude. It is a tributary of the Soan River. The results of observed and computed excess rainfall volume (in inches) of four methods are given in Table 4. Figure 2 shows the comparison of coefficients of determination of various rainfall excess methods with the observed rainfall excess.

Perusal of Table 4 indicates that for Holten loss rate, the value of coefficient of determination $\left(\mathrm{R}^{2}\right)$ is 0.97 . Among other methods used for analysis $\mathrm{R}^{2}$ values are $0.95,0.86$ and 0.83 for SCS, Initial and Uniform and Exponential respectively. A minimum variation is found between observed and estimated rainfall excess and the trend is well preserved by Holtan method, as give in Table 4 and shown in Figure 2. Therefore, this method is considered most accurate for this catchment.

\section{Results for Soan River at Chirah}

This study basin is 126 square miles in size and located at $33^{\circ} 39^{\prime}$ 
Citation: Ahmed TF, Sheikh AA, Hashmi HN, Afzal MA (2017) Comparison of Rainfall Excess Computation Techniques by Hydrological Model. Hydrol Current Res 8: 281. doi: 10.4172/2157-7587.1000281

Page 3 of 5

\begin{tabular}{|c|c|c|c|}
\hline \multirow{2}{*}{ S. No. } & Study Basins & \multicolumn{2}{|c|}{ Gauge Location } \\
\cline { 2 - 4 } & & Latitude & Longitude \\
\hline 1 & Ling River near Kahota (Tributary to Soan River) & 33.36 & 73.22 \\
\hline 2 & Soan River at Chirah (Tributary to Indus River) & 33.39 & 73.13 \\
\hline 4 & Siran River near Phulara (Tributary to Indus River) & 34.2 & 73.23 \\
\hline
\end{tabular}

Source: Alam

Table 1: Physiographic Features of Catchments.

\begin{tabular}{|c|c|c|}
\hline Loss Rate & Parameters & Initial Value \\
\hline \multirow{4}{*}{ 1. Exponential } & STRKR & 0.2 \\
\cline { 2 - 3 } & DLTKR & 0.5 \\
\cline { 2 - 3 } & FTIOL & 2 \\
\cline { 2 - 3 } & ERAIN & 0.5 \\
\hline \multirow{2}{*}{ 2. Initial and Uniform } & STRTL & 1 \\
\hline \multirow{3}{*}{3. Holtan } & CNSTL & 0.1 \\
\hline \multirow{2}{*}{ 4. Curve Number } & FC & 0.01 \\
\cline { 2 - 3 } & GIA & 0.5 \\
\cline { 2 - 3 } & SA & 1 \\
\cline { 2 - 3 } & BEXP & 1.4 \\
\hline \multirow{2}{*}{ T. STRTL } & 1.08 \\
\hline
\end{tabular}

Table 2: Parameters of methods used in HEC-1.

\begin{tabular}{|c|c|c|c|c|c|c|}
\hline \multirow[b]{2}{*}{ Method } & \multirow[b]{2}{*}{ Parameter } & \multirow[b]{2}{*}{$\begin{array}{l}\text { Default } \\
\text { Values }\end{array}$} & \multicolumn{4}{|c|}{ Calibrated Vales of study basins } \\
\hline & & & $\begin{array}{l}\text { Ling } \\
\text { River }\end{array}$ & $\begin{array}{l}\text { Soan } \\
\text { River }\end{array}$ & $\begin{array}{c}\text { Siran } \\
\text { River } \\
\text { (Phulara) }\end{array}$ & $\begin{array}{c}\text { Siran } \\
\text { River } \\
\text { (Thapla) }\end{array}$ \\
\hline \multirow{4}{*}{ Exponential } & STRKR & 0.2 & 0.2 & 0.2 & 0.37 & 0.25 \\
\hline & DLTKR & 0.5 & 0.75 & 0.45 & 0.3 & 1.1 \\
\hline & FTIOL & 2 & 2 & 2 & 2 & 2 \\
\hline & ERAIN & 0.5 & 0.5 & 0.5 & 0.5 & 0.01 \\
\hline \multirow{2}{*}{$\begin{array}{c}\text { Initial and } \\
\text { Uniform }\end{array}$} & STRTL & 1 & 0.17 & 0.1 & 0.3 & 0.39 \\
\hline & CNSTL & 0.1 & 0.1 & 0.1 & 0.1 & 0.1 \\
\hline \multirow{4}{*}{ Holtan } & $\mathrm{FC}$ & 0.01 & 0.01 & 0.01 & 0.01 & 0.01 \\
\hline & GIA & 0.5 & 0.5 & 0.5 & 0.5 & 0.5 \\
\hline & SA & 1 & 0.65 & 0.61 & 0.75 & 1.1 \\
\hline & BEXP & 1.4 & 1.4 & 1.4 & 1.4 & 1.4 \\
\hline \multirow{2}{*}{$\begin{array}{l}\text { Curve } \\
\text { Number }\end{array}$} & STRTL & 1.08 & 0.11 & 0.13 & 0.2 & 0.82 \\
\hline & CRVNBR & 65 & 95 & 94 & 91 & 71 \\
\hline
\end{tabular}

Table 3: Optimized values of parameters for four catchments.

latitudes and $73^{\circ} 18^{\prime}$ longitude. It is tributary to the Indus River and joins Indus at Dhok Pathan. Results of analysis of data using four methods described earlier are presented in Table 5 and Figure 3. For this catchment coefficient of determination computed by exponential method is 0.999 which virtually equal to the observed value of 1 . For Holtan loss rate, the value of $\mathrm{R}^{2}$ is 0.997 , which has more variation than Exponential method but still is very close to the observed value. The value of $\mathrm{R}^{2}$ is 0.96 , for initial and uniform method and in case of SCS method it is 0.94

Although results indicate minimum variation between the observed and computed values of $\mathrm{R}^{2}$ for all methods, exponential method gives least variation. As such, for the selected catchment it can be concluded that exponential method is most reliable for computation purposes.

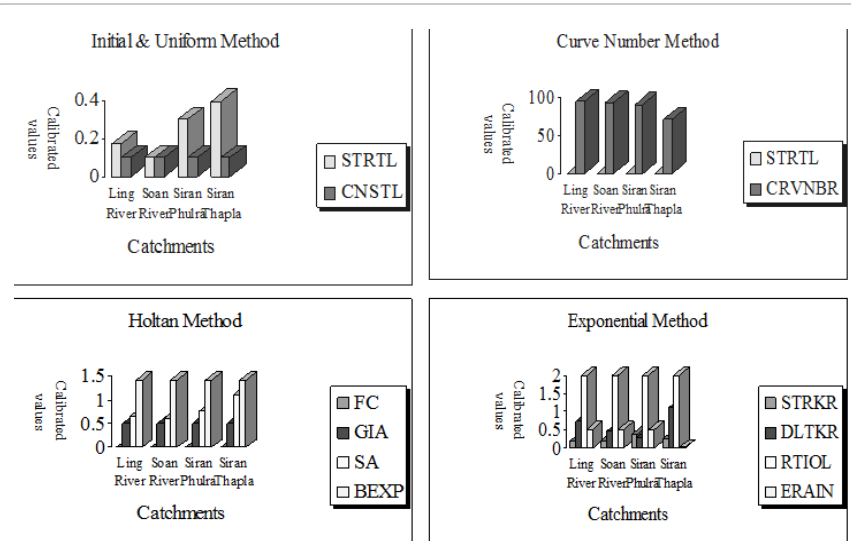

Figure 1: Final optimized values of parameter for each method.

\begin{tabular}{|c|c|c|c|c|c|c|c|c|c|c|c|c|}
\hline \multirow{2}{*}{$\begin{array}{c}\text { Strom } \\
\text { Date }\end{array}$} & \multicolumn{3}{|c|}{ Exponential } & \multicolumn{3}{|c|}{ Holtan } & \multicolumn{3}{c|}{$\begin{array}{c}\text { Initial and } \\
\text { Uniform }\end{array}$} & \multicolumn{3}{c|}{ SCS } \\
\cline { 2 - 15 } & RN & OBS & EST & RN & OBS & EST & RN & OBS & EST & RN & OBS & EST \\
\hline $\begin{array}{c}21-07- \\
1968\end{array}$ & 0.72 & 0.37 & 0.32 & 0.72 & 0.37 & 0.22 & 0.72 & 0.37 & 0.25 & 0.72 & 0.37 & 0.38 \\
\hline $\begin{array}{c}13-08- \\
1970\end{array}$ & 2.37 & 2.34 & 1.67 & 2.37 & 2.34 & 2.31 & 2.37 & 2.34 & 1.78 & 2.37 & 2.34 & 2.14 \\
\hline $\begin{array}{c}01-09- \\
1970\end{array}$ & 2.14 & 1.36 & 1.53 & 2.14 & 1.36 & 1.6 & 2.14 & 1.36 & 1.56 & 2.14 & 1.36 & 1.61 \\
\hline$R^{2}$ & & 1 & 0.829 & & 1 & 0.968 & & 1 & 0.857 & & 1 & 0.951 \\
\hline
\end{tabular}

RN (Rainfall Values); R² (Co-Efficient of Determination); OBS (Observed Values); EST (Estimated Values)

Table 4: Comparison of observed and estimated rainfall excess using HEC-1, Ling River near Kahota (Tributary to Soan River).

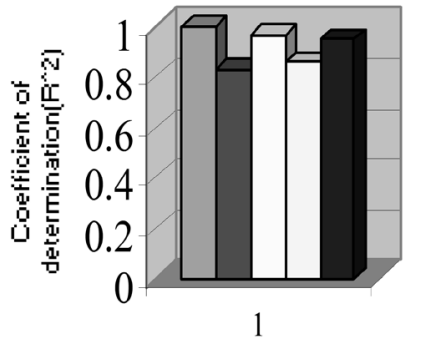

$\mathrm{R}^{\wedge} 2$ Ling

River Near $\square$ Observed

Exponential

$\square$ Holtan

$\square$ Initial \& Uniform

SCS
Figure 2: Comparison of coefficients of determination, Ling River near Kahota. 


\begin{tabular}{|c|c|c|c|c|c|c|c|c|c|c|c|c|}
\hline \multirow{2}{*}{$\begin{array}{c}\text { Strom } \\
\text { Date }\end{array}$} & \multicolumn{3}{|c|}{ Exponential } & \multicolumn{3}{|c|}{ Holtan } & \multicolumn{3}{c|}{$\begin{array}{c}\text { Initial and } \\
\text { Uniform }\end{array}$} & \multicolumn{3}{c|}{ SCS } \\
\cline { 2 - 14 } & RN & OBS & EST & RN & OBS & EST & RN & OBS & EST & RN & OBS & EST \\
\hline $\begin{array}{c}25-07- \\
1974\end{array}$ & 0.98 & 0.61 & 0.57 & 0.98 & 0.61 & 0.56 & 0.98 & 0.61 & 0.6 & 0.98 & 0.61 & 0.57 \\
\hline $\begin{array}{c}06-09- \\
1975\end{array}$ & 1.14 & 0.82 & 0.69 & 1.14 & 0.82 & 0.69 & 1.14 & 0.82 & 0.73 & 1.14 & 0.82 & 0.62 \\
\hline $\begin{array}{c}04-08- \\
1979\end{array}$ & 0.84 & 0.31 & 0.39 & 0.84 & 0.31 & 0.34 & 0.84 & 0.31 & 0.33 & 0.84 & 0.31 & 0.37 \\
\hline$R^{2}$ & & 1 & 1 & & 1 & 0.998 & & 1 & 0.99 & & 1 & 0.947 \\
\hline
\end{tabular}

RN (Rainfall Values); R2 (Co-Efficient of Determination); OBS (Observed Values); EST (Estimated Values)

Table 5: Comparison of observed and estimated rainfall excess using HEC-1, Soan River at Chirah (Tributary to Indus River).

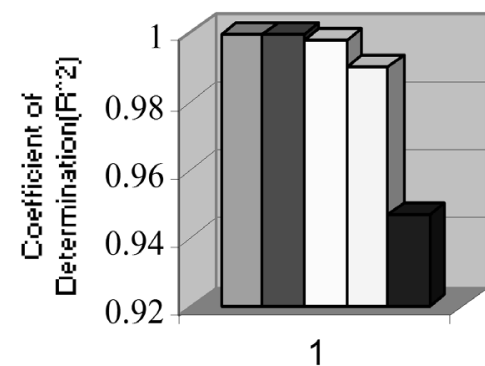

$\mathrm{R}^{\wedge} 2$ Soan

$\square$ Observed
$\square$ Exponential
$\square$ Holtan
$\square$ Initial \& Uniform
$\square$ SCS

River at Chirah
Figure 3: Comparison of coefficients of determination, Soan River at Chirah.

\section{Results for Siran River near Phulra}

Siran rivers is a tributary of River Indus and its catchment area near Phulra extends over 4.8 square miles and is located at $3420^{\prime}$ latitudes and $73^{\circ} 05^{\prime}$ longitude. The results of observed and computed excess rainfall volumes (in inches) by four methods are given in Table 6 and shown in Figure 4. Results are surprising in the case of this catchment. The value of coefficient of determination $\left(\mathrm{R}^{2}\right)$, for Exponential method is 1.00. For Holtan loss rate, the value of co- efficient of determination $\left(\mathrm{R}^{2}\right)$ is 0.250 . The value of co- efficient of determination $\left(\mathrm{R}^{2}\right)$ is 0.00 , for initial and uniform loss method. In the case of SCS method, is the value of co-efficient of determination $\left(\mathrm{R}^{2}\right)$ is also 0.00 .

The results of analysis show that observed and estimated values of $\mathrm{R}^{2}$ are in close conformity i.e., 1.00 and 0.99 respectively using exponential method. $\mathrm{R}^{2}$ values for remaining three methods indicate that these should not be applicable for analysis of data for this catchment.

\section{Results for Siran River near Thapla}

The Siran River at Thapla measures 1080 sq. miles and is located $34^{\circ} 06^{\prime}$ latitude and $72^{\circ} 52^{\prime}$ longitude. Results of analysis of data for excess rainfall is given in Table 7. and shown in Figure 5. For this catchment SCS method results $R^{2}$ values of 0.923 . The value of co-efficient of determination $\left(R^{2}\right)$ is 0.858 , for Exponential loss rate. Holtan loss rate has a $\mathrm{R}^{2}$ of 0.832 and for initial and uniform loss rate, the $\mathrm{R}^{2}$ is 0.759 . The above comparison on the basis of $\mathrm{R}^{2}$ suggests that SCS method is more representative for the catchment under consideration.

\begin{tabular}{|c|c|c|c|c|c|c|c|c|c|c|c|c|}
\hline $\begin{array}{c}\text { Strom } \\
\text { Date }\end{array}$ & \multicolumn{3}{|c|}{ Exponential } & \multicolumn{3}{|c|}{ Holtan } & \multicolumn{3}{c|}{$\begin{array}{c}\text { Initial and } \\
\text { Uniform }\end{array}$} & \multicolumn{3}{c|}{ SCS } \\
\cline { 2 - 14 } & RN & OBS & EST & RN & OBS & EST & RN & OBS & EST & RN & OBS & EST \\
\hline $\begin{array}{c}14-08- \\
1974\end{array}$ & 0.62 & 0.08 & 0.06 & 0.62 & 0.08 & 0.07 & 0.62 & 0.08 & 0.1 & 0.62 & 0.08 & 0.09 \\
\hline $\begin{array}{c}21-07- \\
1979\end{array}$ & 0.1 & 0.08 & 0.06 & 0.1 & 0.08 & 0 & 0.1 & 0 & 0 & 0.1 & 0.08 & 0.01 \\
\hline $\begin{array}{c}19-08- \\
1979\end{array}$ & 0.46 & 0.06 & 0.09 & 0.46 & 0.06 & 0.07 & 0.46 & 0.06 & 0.05 & 0.46 & 0.06 & 0.05 \\
\hline$R^{2}$ & & 1 & 1 & & 1 & 0.25 & & 1 & 0 & & 1 & 0 \\
\hline
\end{tabular}

RN (Rainfall Values); $\mathrm{R}^{2}$ (Co-Efficient of Determination); OBS (Observed Values); EST (Estimated Values)

Table 6: Comparison of observed and estimated rainfall excess using HEC-1, Siran River Near Phulra (Tributary to Indus River)

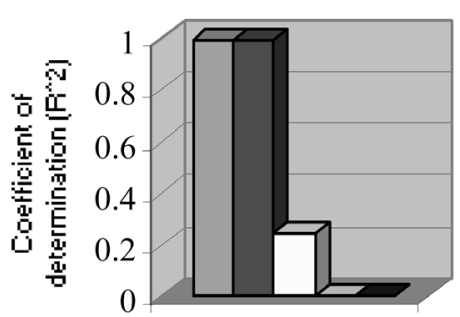

1

$\mathrm{R}^{\wedge} 2$ Siran River near $\square$ Observed

Exponential

$\square$ Holtan

$\square$ Initial \& Uniform

SCS
Figure 4: Comparison of coefficients of determination, Siran River near Phulra.

\begin{tabular}{|c|c|c|c|c|c|c|c|c|c|c|c|c|}
\hline \multirow{2}{*}{$\begin{array}{c}\text { Strom } \\
\text { Date }\end{array}$} & \multicolumn{3}{|c|}{ Exponential } & \multicolumn{3}{|c|}{ Holtan } & \multicolumn{3}{|c|}{$\begin{array}{c}\text { Initial and } \\
\text { Uniform }\end{array}$} & SCS & & \\
\cline { 1 - 12 } & RN & OBS & EST & RN & OBS & EST & RN & OBS & EST & RN & OBS & EST \\
\hline $\begin{array}{c}26-07- \\
1969\end{array}$ & 1.81 & 0.25 & 0.72 & 1.81 & 0.25 & 0.88 & 1.81 & 0.25 & 0.96 & 1.81 & 0.25 & 0.19 \\
\hline $\begin{array}{c}14-08- \\
1969\end{array}$ & 0.61 & 0.15 & 0.04 & 0.61 & 0.15 & 0.06 & 0.61 & 0.15 & 0.17 & 0.61 & 0.15 & 0.11 \\
\hline $\begin{array}{c}02-07- \\
1970\end{array}$ & 0.89 & 0.1 & 0.08 & 0.89 & 0.1 & 0.14 & 0.89 & 0.1 & 0.32 & 0.89 & 0.1 & 0 \\
\hline$R^{2}$ & & 1 & 0.858 & & 1 & 0.832 & & 1 & 0.759 & & 1 & 0.923 \\
\hline
\end{tabular}

RN (Rainfall Values); $R^{2}$ (Co-Efficient of Determination); OBS (Observed Values); EST (Estimated Values)

Table 7: Comparison of observed and estimated rainfall excess using HEC-1, Siran River near Thapla (Tributary to Indus River).

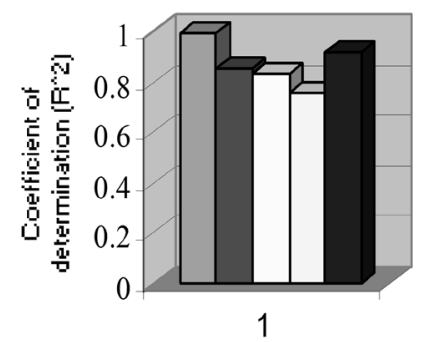

Siran River
口 Observed

$\square$ Exponential

$\square$ Holtan

$\square$ Initial \& Uniform

$\square \mathrm{SCS}$ near Thapla

Figure 5: Comparison of coefficients of determination, Siran River near Thapla. 


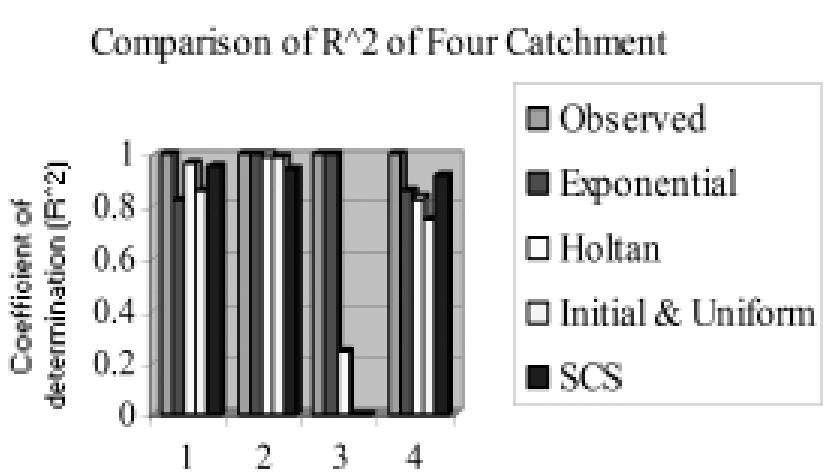

Catchments

Figure 6: Overall Comparison $\left(R^{2}\right)$ of Four Catchments.

\section{Discussion}

Basic objective of the study was to evaluate various excess rainfall estimation methods. Results of various methods show that the overall error using Exponential method is minimum i.e., within acceptable range as shown in Figure 6. It is clear from the analysis that this method can be used effectively for local conditions. The variation in results for some of the storms using this method is large. The reason can be the size of drainage basin. As the size of the catchment increases, the variation in result also increases due to averaging effect of catchment conditions. Exponential excess rainfall estimation method involves the parameters which clearly represent the catchment characteristic.

Other methods cannot be rejected at all. The major factor involves is catchment size. For small size catchments ranging up to 100 square miles, the results are encouraging. For larger areas, it can be said that a catchment must be divided into sub-catchments.

It is also tested whether, the parameters optimized for one areas, are applicable to another physically similar catchment area located in the same hydrological region. The results however, indicate that practically same parameters are not applicable in all cases and from the results of the analysis of two additional catchments it can be assumed that the same parameters can be applied in some cases only, but it requires great deal of caution as the variation could be large.

\section{Conclusion}

It has been concluded that Exponential method of rainfall excess is suitable for local conditions for catchments ranging up to 100 square miles. For larger areas, a catchment should be divided into sub-catchments for effective results. For a different catchment whether physically similar and located in a same hydrological region, a different set of optimized parameters is required. Further study is needed to explore such variations.

\section{Novelty Statement}

The reliability in hydrological investigations is of great importance due to associated infrastructure and protection of human lives. Generally, the hydrological methods developed to compute excess rainfall up till now involve various parameters and coefficients. The relationship between catchment characteristics and rainfall excess vary from region to region as they show the composite effect of all other characteristics which are not even considered in the relationships. The scope of the study is limited to small watersheds with insignificant snowmelt effect in producing runoff. The novelty in the study is the comparative analysis of different excess rainfall methods in order to evaluate an appropriate method for the local conditions especially for ungauged catchments.

\section{References}

1. Alam MM (1983) Development of Synthetic Unit Hydrograph in Small Catchments of Pakistan. Thesis for the degree of Master of Philosophy in Hydrology, CEWRE, UET, Lahore.

2. Chow VT (1962) Hydrologic Determination of Waterway Areas for the Design of Drainage Structures in Small Drainage Basins. Univ Illinois Eng Erp Sta Bull 462.

3. Cook HL (1946) The infiltration approach to the calculation of surface runoff. Eos, Transactions American Geophysical Union 27.5: 726-747.

4. Chow VT (1964) Handbook of Applied Hydrology. McGraw-Hill New York, New York, USA, p: 1418.

5. Falkland A (1991) Hydrology and Water Resources of Small Islands a Practical Guide. Studies and Reports in Hydrology.

6. Garklavs G, Oberg AK (1986) Effect of Rainfall Excess Calculations on Modeled Hydrograph Accuracy and Unit-Hydrograph Parameters. Water Resources Bulletin, American Water Resources Association 22: 565-572.

7. Linsley RK, Kohler MA, Paulhus JLH (1975) Hydrology for Engineers. 2nd edn, McGraw-Hill, p: 482.

8. Morel-Seytoux HJ (1981) Application of Infiltration Theory for the Determination of Excess Rainfall Hyetograph. Water Resources Bulletin, American Water Resources Association Bulletin Am WR Am 17: 1012-1022. 